\title{
Antibacterial effect of Dodonea viscosa (hop bush) leaf extract in some enterobacteriaceae
}

\begin{abstract}
This study was conducted to determine the Antibacterial Effects of the Leaves Extracts of Dodonea viscosa (D. viscosa). In Some Enterobacteriaceae with in Federal University Dutsinma by using different solvents: Ethanol, Petroleum ether and Distilled water. The agar well diffusion method was used to determine the inhibitory actions of these extracts with four concentrations: $1000,2000,3000$, and $4000 \mu \mathrm{g} / \mathrm{ml}$. The study revealed that the aqueous extracts of $D$. viscosa have the higher percentage yield of $20.46 \%$ compared to the ethanolic and petroleum ether extracts. It further shows that saponins, tannins and phenols were present in all the three extracts, while Flavonoids were present in the aqueous and ethanolic extracts and alkaloids present only in the ethanolic extracts. The result also shows that the leaf extract of $D$. viscosa exhibited some degree of antibacterial activity on some of the test bacteria used. Other solvent should also be used for extraction of other parts of the plant to reveal their potentials.
\end{abstract}

Keywords: antibacterial, dodonea viscose, leaf extract, enterobacteriaceae
Volume 8 Issue 2 - 2018

Orpin JB, Bem AA, Inuwa A

Department of Biological \& Faculty of Science, Federal

University, Nigeria

Correspondence: Orpin JB, Department of Biological \& Faculty of Science, Federal University, Nigeria,

Email jorpin@fudutsinma.edu.ng

Received: February II, 2018 | Published: April 26, 2018

\section{Introduction}

Dodonea viscosa is a shrub of flowering plant in the soapberry family, Sapindaceae that has cosmopolitan distribution. The center of origin is believed to be Australia, but it occurs throughout the tropics and subtropics, widely distributed in temperate regions of Australia, Africa, Mexico, New Zealand, India, Northern Mariana Islands, Virginia Islands, Florida, Arizona, South America. ${ }^{1}$ These flowers occur during spring and summer and are less than a centimeter in size. The plants are dioecious; the flowers are male or female and usually on separate plants. ${ }^{2} D$. viscosa has many medicinal properties and has been used by native peoples from all regions where it is found. It is traditional medicine worldwide, administered orally or as poultice to treat great variety of ailments ${ }^{1,2}$ The stems and leaves are used to treat fever and seeds in sore throat; root infusion to treat cold and seeds (in combination with those of other plants and coated in honey) to treat malaria. The stems are used as fumigants to treat rheumatism. The leaves are used to relieve itching, fevers, swellings, aches and can be used as antispasmodic agent, leaves and roots as painkiller to soothe toothaches and headaches, and lotion made from unspecified plant parts to treat sprains, bruises, burns and wounds. Digestive system disorders, including indigestion, diarrhea and constipation are commonly treated in traditional medicine with an orally administered decoction of either leaves or roots. Trachoma is treated with applications of leaf juice, and powdered leaves are given to expel roundworms. Pulverized roots are a component of antihelmintic preparations. The roots, either in decoction of fresh, are taken by women in East Africa to stimulate milk production after giving birth and to treat dysmenorrhea and irregular menstruation. ${ }^{1,2}$ The flowers are used as a "home-brew" substitute to bestow a bitter flavor. Dodonea viscosa, which belongs to the family Sapindaceae, is used as a traditional medicine in different countries. Stem or leaf infusions were used to treat sore throats, Root infusion to treat colds and Seeds in combination with other plants is used to treat malaria. The leaves are used to treat itching, digestive system disorders, including indigestion, ulcers and diarrhea and the powdered leaves were given to expel round worms. ${ }^{3}$ The plant is also used as antibacterial ${ }^{4}$ and also has an insecticidal activity. ${ }^{5}$ The active principle constituents of $D$. viscosa is an acid resin, Leaves contain two acid resins, gum, albumen, tannin, and ash. Study of leaves yielded carbohydrates, Flavonoids, fixed oil, proteins and amino acids, saponins, steroids and sterols, tannins, and triterpenoids. ${ }^{6}$ Studies conducted by ${ }^{6}$ further indicated that $D$. viscosa showed promising antimicrobial activity against both Gram-positive and Gram-negative organisms. The bark decoction of D. viscosa, In Ethiopia, it is used for skin diseases. In Peru, the sour and bitter leaves are chewed for its stimulant effect, like coca leaves. Powdered leaves are applied on wounds which would then heal without scars and Leaves are applied to burns and scalds. In India, it is used in the treatment of headaches, backaches, stomach pains, piles and simple ulcers. Leaves are used in treatment of rheumatism, gout, hemorrhoids, fractures, and snake bites.?

\section{Justification}

It has been established that the use of herbs and medicinal plant in Africa for therapeutic purpose has been quite a common practice. However most of these plant and herbs are used indiscriminately without proper knowledge of their chemical constituents, spectrum of activity, and inhibitory or bactericidal concentration. Furthermore, due to the widespread and often indiscriminate use of antimicrobial drugs, microorganisms have acquired resistance to specific antibiotic treatments. Thus, there is need to conduct researches to discover the active component and the antimicrobial activities of medicinal plant so as to overcome the increasing trend of microbial resistance to the conventional antibiotics. This work was therefore carried out to determine the Antibacterial Effect of $D$. viscosa leaf extract in some Enterobacteriaceae within Federal University Dutsinma.

\section{Aim and objectives}

The aim of this study was to determine the Antibacterial Effect of Dodonea viscosa Leaf Extract in some Enterobacteriaceae within Federal University Dutsinma with the following objectives: 
a. To extract leaf of $D$. viscosa using ethanol, petroleum ether and water.

b. To determine the Phytochemical compounds of D. viscosa leaf extract.

c. To establish the antibacterial activity of the extract in some Enterobacteriaceae.

\section{Materials and methods}

\section{Study area}

The study was conducted in Dutsinma Local Government Area, Katsina State. It is located on Latitude $12^{\circ} 27^{\prime} 18^{\prime \prime} \mathrm{N}$ and longitude $7^{\circ}$ 29'29' $\mathrm{E}$ and has its headquarters in the town of Dutsinma. It has an estimated area of $527 \mathrm{~km}^{2}(203 \mathrm{sqkm})$ and a population of 169,671 as at 2006 census. ${ }^{8}$ The population and activities in the local government area have increased in the last 3 years which may be due to the establishment of the new Federal University. The Local Government is bounded by Kurfi and Charanchi Local Governments to the North, Kankia Local Government to the East, Safana and Dan- Musa Local Governments to the West, and Matazu Local.nt to the Southeast. The people are predominantly farmers, cattle rearers and traders (Figure $1)$.

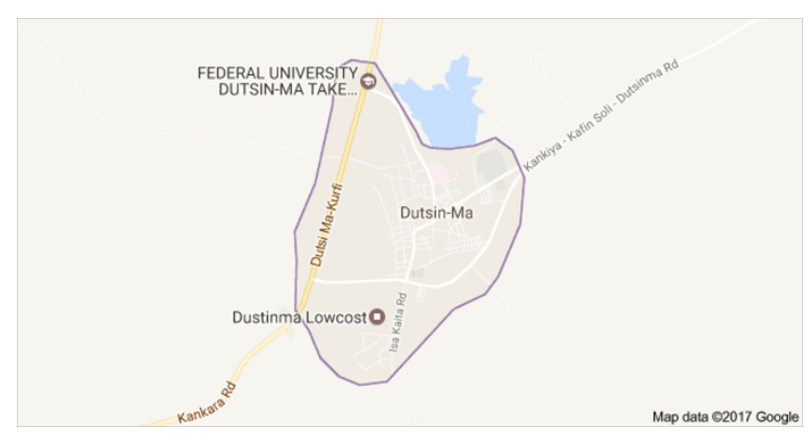

Figure I Map of Katsina State showing Federal University Dutsinma.

\section{Sample collection}

Leaves of $D$. viscosa were freshly collected from a fully grown plant within Federal University Dutsinma and taken to the herbarium unit of Ahmadu Bello University Zaria for identification. Identified by Mr. Namadi at the herbarium section with voucher number 900241.

\section{Preparation of aqueous and organic solvent extracts}

The aqueous extraction was done by cold percolation method according to. ${ }^{9} 50 \mathrm{~g}$ of the powder was soaked into $500 \mathrm{ml}$ of distilled water and Left to stand for $48 \mathrm{hrs}$ at room temperature with regular shaking. It was then filtered using what mans number one filter paper. The extract was concentrated in water bath at $40^{\circ} \mathrm{C}^{10}$ and stored at $4^{\circ} \mathrm{C}$ Fifty gram $(50 \mathrm{~g})$ of each of the powdered material were then extracted separately with ethanol $(95 \%)$ and pet ether using the soxhlet apparatus as described by. ${ }^{10}$

\section{Sterility of the extracts}

After filtration, the extracts were tested for sterility by introducing $1 \mathrm{ml}$ of each of the extracts into $15 \mathrm{ml}$ of sterile nutrient broth. Incubation was done at $37^{\circ} \mathrm{C}$ for $24 \mathrm{hrs}$. A sterile extract is indicated by absence of turbidity or clearness of the broth after incubation period. ${ }^{11}$

\section{Phytochemical screening}

Phytochemical screening of the extract was carried out at Chemistry laboratory of Federal University Dutsinma, according to the method described by. ${ }^{11}$

\section{Test for alkaloids}

Two to three (2-3) drops of each of Meyers reagent was added to $1.0 \mathrm{ml}$ of the extracts in a test tube. A white precipitate indicates the presence of alkaloid. ${ }^{11}$

\section{Test for saponins}

Five (5) $\mathrm{ml}$ of distilled water was added to $0.5 \mathrm{~g}$ of the powder in a test tube and shake vigorously. A persistence froth that lasted for 15 mins indicates the presence of saponins. ${ }^{11}$

\section{Test for phenols}

Equal volume $(0.2 \mathrm{ml})$ of the plant extract and ferric acid chloride $\left(\mathrm{FeCL}_{3}\right)$ were mixed. The developments of deep blue green coloration indicates the presence of phenol. ${ }^{11}$

\section{Preparation of stock solution}

Stock solution was prepared by mixing $0.1 \mathrm{~g}$ of the dried extract recovered with $1 \mathrm{ml}$ of $\mathrm{DMSO}_{4}$ in a sterile bijou bottle and allow to dissolve $(100,000 \mu \mathrm{g} / \mathrm{ml})$. Sub stock solution is prepared by mixing $0.1 \mathrm{ml}$ of the stock solution and $0.9 \mathrm{ml}$ of $\mathrm{DMSO}_{4}(10000 \mu \mathrm{g} / \mathrm{ml})$. Then the concentration $(4000 \mu \mathrm{g} / \mathrm{ml}, 3000 \mu \mathrm{g} / \mathrm{ml}, 2000 \mu \mathrm{g} / \mathrm{ml}$ and $1000 \mu \mathrm{g} /$ $\mathrm{ml}$ ) where prepared in addition to control treatment. ${ }^{12}$

\section{Biochemical identification of test organism}

The test organisms were pathogenic organisms clinically isolated from Microbiology laboratory of General Hospital Dutsinma, Katsina. A Series of biochemical test were carried out to identify them including indole, motility, citrate utilization, urease, hydrogen sulphide and acid and gas production according to standard procedures described by. ${ }^{12}$

\section{Escherichia coli}

The isolate was cultured on Eosine Metheylene blue agar for 24-48hrs. Colonies with green metallic shade were observed which indicate a positive result for $E$. coli, the colonies where subjected to IMVIC test were E.coli gives Indole and mythel red positive, VogesProskauer and citrate negative. ${ }^{12}$

\section{Salmonella spp}

The organism where identified by culturing on MAC Agar, colorless colonies which represent non lactose fermenters where observed and subculture on deoxycolate agar (DCA). Colorless colonies with a black spot were observed which indicate hydrogen sulphite production by salmonella. It was further cultured on simmon's citrate agar slant for $24 \mathrm{hrs}$.Adeep blue or royal blue coloration indicates positive result. Finally, the organisms were further subjected on TSI to differentiate S.typhi from S.typhimurium. ${ }^{12}$

\section{Pseudomonas spp}

The organism where identified by culturing on MAC Agar for 24-48hrs, colorless colonies which represent non lactose fermenters were observed. The organism were further subjected to IMVIC were the P.aeroginosa give indole and methyl red negative and VogesProskauer and citrate negative. ${ }^{12}$ 


\section{Klebsiella spp}

The isolate was cultured on MAC Agar, which ferment lactose to lactic and yielded a positive result on both Voges-Proskauer and Methyl red test. ${ }^{12}$

\section{Antibacterial susceptibility assay}

The agar well diffusion method previously described by ${ }^{13,14}$ was used for the determination of antibacterial activity of the plant extracts. A loopful of the Standardized bacterial suspension was swabbed on the surface of solidified and dried Nutrient agar plates in separate Petri dishes. Thereafter, wells were made by using sterilized cork borer $(6 \mathrm{~mm})$. Then the extracts were introduced into the wells, and ceftriaxone was used as control. The plates were incubated for 24 hours at $37^{\circ} \mathrm{C}$. The experiment was performed two times and the activity of plant extracts was determined by measuring the diameter of inhibition zone around each well in millimeter. ${ }^{15}$

\section{Results}

The result in Table 1 show that, Aqueous extracts of D.viscosa yielded $10.23 \mathrm{~g}$ with a percentage yield of $20.46 \%$ while ethanolic $7.8 \mathrm{~g}(15.6 \%)$ and petroleum ether $9.9 \mathrm{~g}(19.8 \%)$ in soxhlet and flask extraction procedures.

Table I Extraction of D.Viscosa leaves

\begin{tabular}{llll}
\hline Properties & Aqueous & Ethanolic & $\begin{array}{l}\text { Petroleum } \\
\text { ether }\end{array}$ \\
\hline $\begin{array}{l}\text { Weight of plant } \\
\text { leaves (grams) }\end{array}$ & 50 & 50 & 50 \\
$\begin{array}{l}\text { Weight of extract } \\
\text { recovered (grams) }\end{array}$ & 10.23 & 7.8 & 9.9 \\
$\begin{array}{l}\text { Percentage Yield (\%) } \\
\text { Colour }\end{array}$ & 20.46 & 15.6 & 19.8 \\
\hline
\end{tabular}

\section{Phytochemical screening of $D$. viscosa leaf extract}

Data from Table 1 show the Phytochemical screening of $D$. viscosa extracts indicating the presence of some secondary metabolites and compounds. Saponins, tannins and phenols were detected in all the three extracts. Flavonoids were only detected in the aqueous extract and alkaloids were not detected only in the ethanolic extract. Neither alkaloids nor were Flavonoids detected in Petroleum Ether extract. Volatile Oils were detected only not in aqueous extract.

\section{Antibacterial activity of $D$. viscosa leaf extract by agar well diffusion assay}

The antimicrobial assay using agar well diffusion method showed all the extracts: Aqueous, Ethanol, as well as Petroleum ether has some degree of activity against some of the isolates. The result of the susceptibility test shows $S$. typhi responded to all the extracts at $4000(\mu / \mathrm{ml})$ and $3000(\mu / \mathrm{ml})$ likewise $P$. aeruginosa. The highest zone of inhibition for the extract was $11.67 \mathrm{mmat} 4000(\mu / \mathrm{ml})$. While the lowest zone of inhibition was $7.33 \mathrm{~mm}$. S. typhi was the most sensitive organism to the ethanolic extract with zones of inhibitions up to $11.67 \mathrm{~mm}$, while $E$. coli was the least sensitive organism to the ethanolic extract with a zone of inhibition of $7.67 \mathrm{~mm}$. E. coli and $K$. pneumoniae only responded to ethanolic extract at $4000(\mu / \mathrm{ml})$ and $3000(\mu / \mathrm{ml})$. E. coli and $K$. pneumoniae resisted the petroleum ether and aqueous extract, and even the S. typhi and P. aeruginosa barely showed a significant response. When compared with ceftriazone (Positive control), The test organisms were more sensitive with zones of inhibition of up to $33.33 \mathrm{~mm}$ on $S$. typhi while the lowest zone of $29.33 \mathrm{~mm}$ was on $K$. pneumoniae.

\section{Discussion}

Table 1 shows that the ethanol and petroleum ether extracts gave the high yield of $15.6 \%$ with a dark brown color and $19.8 \%$ with dark green color and aqueous gave the yield of $20.46 \%$ with a pale green color. The results differ from those of Abdul et al. ${ }^{16}$ Who demonstrated that ethanol and petroleum ether gave the low yield of $2.3 \%$ with a brown colour and $0.6 \%$ with a Dark green color. And aqueous gave $1.6 \%$ with a green color. It also shows that the concentrations of ethanolic extracts at $4000 \mu \mathrm{g} / \mathrm{ml}$ and $3000 \mu \mathrm{g} / \mathrm{ml}$ of the compound responsible for the antibacterial activity is higher than petroleum ether and aqueous extracts. This result differs from those of Getie et al. ${ }^{17}$ who demonstrated that ethanolic extracts at concentration of $4000 \mu \mathrm{g} /$ $\mathrm{ml}$ and $3000 \mu \mathrm{g} / \mathrm{ml}$ showed weak antibacterial effect against the test organisms. At concentration of $2000 \mu \mathrm{g} / \mathrm{ml}$ and $1000 \mu \mathrm{g} / \mathrm{ml}$ no activity is seen across all extracts because compounds responsible for the antibacterial activity are least in concentration. This agrees with the work conducted by. ${ }^{16}$ The antibacterial effect of the leaf extract against E.col and P. aeroginosa were in agreement with the result of Teffo, ${ }^{18}$ Rojas et al. ${ }^{4}$, Mothana et al. ${ }^{19}$ who in their separate researches revealed that extracts of $D$. viscosa exhibited significant antibacterial activity. Table 2 shows the results of the Phytochemical screening compared as it agrees with the works of Hassan et al. ${ }^{20}$ Faruq et al., ${ }^{21}$ Olafimihan. ${ }^{22}$ The classes of compounds are known to show curative activity and is therefore not surprising that the plant leaves are used traditionally as an analgesic, antimicrobial and soothing herbs. The Phytochemical analysis showed that Alkaloids, Tannins, Saponins, Flavonoids, Volatile oil and phenols were detected in ethanolic extracts. These bioactive components are known to be bactericidal, pesticides, or fungicidal in nature thus conferring the antimicrobial property of plants and this agrees with the work of. ${ }^{23}$ Table 3 shows Escherichia coli was less susceptible to the ethanolic leaf extract and showed a diameter of inhibition zone of $9 \mathrm{~mm}$ and $7.67 \mathrm{~mm}$ at the concentration of $4000 \mu \mathrm{g} / \mathrm{ml}$ and $3000 \mu \mathrm{g} / \mathrm{ml}$ respectively. The less sensitivity of this bacterium may be due to the presence of plasmid conferring resistance which agrees with the report of..$^{24,25}$

Table 2 Phytochemical screening of D.viscosa leaf extract

\begin{tabular}{llll}
\hline Properties & Aqueous & Ethanolic & Petroleum ether \\
\hline Alkaloids & - & + & - \\
Flavonoids & + & + & - \\
Saponins & + & + & + \\
Volatile oil & - & + & + \\
Tannins & + & + & + \\
\hline Phenols & + & + & + \\
\hline
\end{tabular}

Key;

$+=$ detected

- = not detected 
Table 3 Antibacterial activity of D. viscosa leaf extract (mean diameter zone of inhibition in $\mathrm{mm}$ )

\begin{tabular}{|c|c|c|c|c|c|c|c|c|c|c|c|c|c|}
\hline Concentration & Aqueous & & & & Ethanolic & & & & Petroleun & ther & & & Ceftriazone \\
\hline & $(\mu \mathrm{g} / \mathrm{ml})$ & & & & $(\mu \mathrm{g} / \mathrm{ml})$ & & & & $(\mu \mathrm{g} / \mathrm{ml})$ & & & & $(\mu \mathrm{g} / \mathrm{ml})$ \\
\hline ISOLATES & $A$ & B & C & $\mathrm{D}$ & $A$ & B & C & D & $A$ & B & C & $\mathrm{D}$ & \\
\hline S. typhi & $10.67 \pm 0.58$ & $7.67 \pm 0.58$ & 0 & 0 & 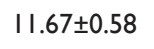 & $8.67 \pm 058$ & 0 & 0 & $8.33 \pm 0.58$ & $7.67 \pm 0.58$ & 0 & 0 & $33.33 \pm 0.58$ \\
\hline P.aeruginosa & $9.33 \pm 0.58$ & $7.33 \pm 0.58$ & 0 & 0 & $10.33 \pm 0.58$ & $7.33 \pm 0.58$ & 0 & 0 & $7.67 \pm 0.58$ & $7.33 \pm 0.58$ & 0 & 0 & $30 \pm 1$ \\
\hline E.coli & 0 & 0 & 0 & 0 & $9 \pm 1$ & $7.67 \pm 0.58$ & 0 & 0 & 0 & 0 & 0 & 0 & $30 \pm 1$ \\
\hline K.pneumoniae & 0 & 0 & 0 & 0 & $8.67 \pm 0.58$ & 0 & 0 & 0 & 0 & 0 & 0 & 0 & $29.33 \pm 0.58$ \\
\hline
\end{tabular}

$[A]=4000(\mu \mathrm{g} / \mathrm{ml}) ;[B]=3000(\mu \mathrm{g} / \mathrm{ml}) ;[\mathrm{C}]=2000(\mu \mathrm{g} / \mathrm{ml}) ;[\mathrm{D}]=1000(\mu \mathrm{g} / \mathrm{ml}) ;[$ Figure values $]=$ susceptibility; [0]=resistance; [ \pm value $]=$ standard deviation

\section{Conclusion}

The study revealed that aqueous extracts of $D$. viscosa had the highest percentage yield of $20.46 \%$ compared to the ethanolic and petroleum ether extracts. It further showed that saponins, tannins, and phenols were present in all the three extracts used, while Flavonoids was present in aqueous and ethanolic extracts only and alkaloids present only in the ethanolic extracts. D. viscosa was seen to have some antibacterial activity against some of the test bacteria, in this study with the ethanolic extracts exhibiting higher zones of inhibition compared to the other extracts.

\section{Recommendation}

Further research should be carried out to determine the specific active compounds responsible for the activity of the plant against different organism

Other solvent should also be used for extraction of other parts of the plant to reveal their potentials.

\section{Acknowledgments}

None.

\section{Conflict of interest}

The authors declared there is no conflict of interest.

\section{References}

1. Sandhya R, Rao Pipalla S, Krishna M. An overview of Dodonaea viscosa linn. J Ethnopharmacol. 2008; 118(1):173-176.

2. Aliyu BS. Common Ethnomedicinal Plants of the Semi-Arid Regions of West Africa: Their Descriptions and Phytochemicals. USA: Triumph Publishing Co. Ltd; 2006. 93-94p.

3. Vanwelzen PC. Dodonaea viscosa (Jacq.). In: editors. Plant Resources of South-East Asia. Medicinal and poisonous plants 2. Backhuys Publishers, Leiden, Netherlands. 2001;12(2):234-237.

4. Rojas A, Hernandez L, Pereda MR et al. Screening for antimicrobial activity of crude drug extracts and pure natural products from Mexican medicinal plants. J Ethno pharmacology. 1992;35(3):275-283.

5. Malarvannan S, Kumar SS, Prabavathy VR, et al. Individual and Synergistic effects of Leaf Powder of Few Medicinal Plants against American Bollworm, Helicoverpa armigera (Hubner) (Noctuidae: Lepidoptera). Asian J Exp Sic. 2008;22(1):79-88.
6. Shaikh MI. Trees of Pakistan. Islamabad: Pictorial Printing (Pvt) Ltd. 1993;27(1):131-162.

7. Aruna M,Asha VV. Gastroprotective effects of Dodonaea viscosa on various experimental ulcer models, J Ethnopharmacol. 2008;118(3):460-465.

8. National Population Commission Census. Federal republic of Nigeria official Gazette number 24. Nigeria: The Federal Government Katsina; 2006. 25 p.

9. Veeramuthu V, Badiger S, Nayak V, et al. Antiulcerogenic activity of various extracts of Dodonaea viscosa (L) jacq leaves. Indian Journal of Pharmaceutical Sciences. 2006;66(4):407-411.

10. Sofowora A. Medicinal plants and Traditional Medicines in Africa. New York: Wiley \& Sons; 1993. 34-36p.

11. Poongothai A, Sreena KP, Sreejith K, et al. Preliminary phytochemicals screening of Ficus racemosa lin bark. J Pharm Biol Sci. 2011;2:431-434.

12. Cheesbrough M. Medical Laboratory Practice in Tropical countries. Part 2, $2^{\text {nd }}$ ed. United Kingdom: Cambridge University Press; 2006. 157-200 p.

13. Atata R, Sani A, Ajewole SM. Effect of stem bark extracts of Enantia chlorenta on some clinical isolates. Biokemistri. 2003;15:84-92.

14. Nester EW, Evans RC, Nancy NP et al. Microbiology: A human perspective. $2^{\text {nd }}$ ed. USA: WBC McGraw Hill; 1998. 447-461 p.

15. NCCLS. Performance standards for Antimicrobial Disk Susceptibility Tests. $4^{\text {th }}$ ed. Villanova, Pennsylvania: The National Committee for Clinical Laboratory Standards; $1990.125-150$ p.

16. Abdul R, Ahameethunisa T, Waheeta R et al. Antibacterial activity of Dodonaea viscosa against clinical and phytopathogenic bacteria. $J$ Ethnopharmacology. 2010;10:6-16.

17. Getie M, Mariam TG, Rietz R, et al. Evaluation of anti- microbial and antiinflammatory activities of the medicinal plants: Dodonaea viscosa, Rumex nervosus and Rumex abyssinicus. Fitoterapia. 2003;74(1-2):139-143.

18. Teffo LS. Nutritional and Medicinal value of the edible stinkbug, Encosternum delegorguei Spinola cousumed in the Limpopo Province of South Africa and its host plant Dodonaea viscosea Jacq. Doctoral thesis, University of Pretoria: South Africa; 2007.

19. Mothana RA, Abdo SA, Hasson S, et al. Antimicrobial, Antioxidant and Cytotoxic Activities and chemical Screening of Some Yemeni Medicinal Plants. Evid Based Complement Alternat Med. 2010;7(3):333-330.

20. Hassan MM, Oyewale AO, Amupitan JO, et al. Preliminary Phytochemical and antibacterial investigation of crude extracts of the leaf of Detarium microcapum. J Chem Soc Nig. 2004;29:26-29. 
21. Faruq UZ, Adul-malik M, Dabai YU. Antibacterial activity of crude extract of Senna leaves. Biosci Res Comm. 2004;16:7-13.

22. Olafimihan CA. Effects of seasonal Variation on the antibacterial activities of aqueous extracts of Azadirachta indica. Biosci Res Comm. 2004;16:13-16

23. Eloff JN. Antibacterial and Phytochemical screening of antimicrobial components from plants. Ethnopharmacol. 1998;60:18-24.
24. Neoji U, Saumya R, Mishra PK et al. Lipid content and in vitro Antimicrobial Activity of Oil Seeds of Some Indian Medical Plants. Curr Res Bacteriol. 2008;1(1):1-6.

25. Lawal D, Mukhtar MD, Taura DW. A study of the phytochemical properties and Synergistic Action of Leaf Extracts of Dodonaea viscosa Linn, Annona Comosus (Linn) Mere Peel and Citrus Senesis Peel on Aeromonas hydrophila and Salmonella Species. Journal of Natural Sciences Research. 2012;2(6):2224-3186. 